\title{
Influence Of Motivation On Teachers Performance In A Local Government Area In Nigeria
}

\author{
\#Meindinyo R. O K, *Ikurite N. \\ \#Department of Physics, Niger Delta University, Wilberforce Island, Amasoma, Nigeria. *Isaac JasperBoro \\ College of Education Sagbama Nigeria.
}

\begin{abstract}
The hue and cry over the falling standard of education in Nigeria has assumed alarming dimensions in recent years. This has equally evoked tremendous research interests to investigate the possible causes of this ugly development. Some have blamed It on lack of motivation of teachers while others on lack of necessary facilities and so forth. This work presents the results of a survey conducted in a particular local government area in Nigeria as to how motivation may influence teachers performance. The research instrument used for the study was a two-part 35 items questionnaire which was meant to test the influence motivation may have on teachers performance. It was administered to 100 randomly selected teachers from 10 of the sampled secondary schools used for the study. Seven research questions were analyzed and series of cross tabulations were used for the analysis. The data collected were analyzed by means of frequencies and percentages of the various responses provided by the teachers. The study revealed that: applying the right motivation factor has positive influence on teachers performance.That the factors that are currently being used to motivate teachers namely; annual gettogether parties Organizing send-off parties for teachers on transfer, Constant supervision of teacher's work, provision of attendance register and provision of movement books have minimal influence on teachers performance That factor such as age, sexprofessional training may affect a teacher's performance.Based on these findings it was recommend that; management of secondary schools should make use of correct motivational strategies such as attitude motivation, incentives, and recognition. there should be regular training for teachers workshops to motivate teacher for higher productivity. government should always try as much as possible to pay teachers' salaries promptly and regularly. management of the schools try and provide accommodation to teachers within the school premises and teachers should be given opportunities to develop themselves through study-leave with pay or in service -training.
\end{abstract}

Key words :- Motivation, teacher's performance Local Government Area.

\section{INTRODUCTION}

In recent years there has been growing concern over the falling standard of education in Nigeria which is premised on the consistent abysmal performances of students in public examinations. A number of factors are suggested to be responsible which include poor attitude of students to learning, lack of infrastructure and teacher's aids, leadership issues and such others Meindinyo et al (2017), as well as motivation of teachers, Ajayi $(1983,2009)$. According to Ayayi motivation cannot seen but its presence can only be assumed. In general, motivation of workers from various originations continue to remain a challenge to managers over the years, including the education sector. The implementation committee on the national policy on Education in Nigerian may have recognized the teachers plight when it recommended that teachers should be treated in such a way that they have job satisfaction.However, issues of how to motivate teachers to give them more satisfaction with their jobs continued to engage the attention of government's educational administrators and educational policy makes but without much success, for not much has been done to actually motivate the teachers and the resultant effects of this are that,many people see the teaching professional as a gate-way or stepping-stone to better jobs.Many in the profession attempt to combine teaching with some other endeavors such trading and are thus distracted and their morale is usually very low.

Nwankwo (1982) writing on staff motivation in schools pointed out that, "the problem of what to do make teachers work hard for the interest of the school and in their own interest is a fundamental one. Effective staff motivation demands that, on the one hand, the teachers be so engineered to devote themselves to achieve the objectives of education, the school or of the students, and on the other hand, that the individual teacher's goal and needs be met. Several writers associated staff motivation with the satisfaction of the needs of a staff. That the more the needs of the workers are satisfied within the organization, the more they are motivated to work and thus satisfy the needs of the organization.Similarly, Nwagu (1976), pointed out that productivity in education, which is very crucial to economic productivity, depends primarily (though not entirely) on teachers competence. Whereas an increase in productivity in manufacturing textiles may be due to many causes, some of 
which might be extraneous to the industry, but the general causes of any increase in educational productivity will probably be the result of greater by teachers.Likewise Likert (1961) in emphasizing leadership style as an aspect of motivation put it thus, "those managers who are seen by their workers as unselfish, co-operative and sympathetic are much more apt to be in-charge of superior agencies than those seen as the opposite". Studies as those of Mann (1964),Harman(2009),Inbar(2009) arrived at findings that, workers who are free to set their own work pace, prove to be more productive than workers who lack that sense of freedom.Ajibade (1984) in his study also emphasized the importance of staff motivation. According to him, whichever leadership style being used by principals of schools should ensure that teachers are motivated towards higher task productivity.Maslow (1943) came up with his theory of "Need Hierarchy" which he based on three assumptions:Thathuman beings are wanting animals whose wants are determined by what they have, That a satisfied need is not a determinant of human behaviour. That human needs exist in a hierarchy according to importance.Maslow listed his hierarchy of needs in ascending order of importance as: Physiological needs, security/safety, social, self-esteem or ego and self-actualization.Maslow believed that a satisfied need no longer motivates and then the effort to satisfy the next need is focused upon. He therefore advocated that, to motivate staff to high level of performance, it is necessary to find out what their needs are, and see that while they are striving to achieve the organizational goals, they should be made to satisfy their own needs alongside. It is only then that they can personalize their efforts and be made to increase their efforts. In every organization, the most important functions are the achievement of the organizational goals. This presupposes every worker in an organization of the organizational goals. Organizations cannot operate alone without the involvement of human beings who are employed to handle the jobs, and it is the performance of these staff that will lead to success or failure of the organization. It is therefore imperative that every organization gives great attention to the performance of its workers, so as to ensure effectiveness and high productivity. In education especially, attention should be given to the level of performance of the teachers and principals, since they are in the forefront of those people who are responsible for achieving the goals of the school.According to Luthans (1979)Goldman (2002) motivation has direct implication for the consequences of the performance and its satisfaction. Duncan (1978) on his part asserted that, motivation relates to all aspects of individual behaviour, when a conscious attempt is made on the part of managers to influence the direction and rate of that behaviour. In other words, to motivate staff to a high level of performance, the administrator might need to create some motivational stimuli or strategy which the worker perceives, and which therefore influences his behaviour. What we know about motivation helps us to gain an insight into the individual differences of the workers. It also further exposes the light on why people behave the way they do and why they prefer to do things in one way, rather than another.Atkinson (1961) argues that "motivation has to do with the analysis of the various factors which incite and direct an individual's action. For a teacher to perform in a way that will be successful and productive, his behaviour might have to be motivated since it is generally agreed among psychologists that motivated behaviour is often goal oriented. From the few assertions above, there appears to be an agreement on the fact that to motivate, management should find out the needs of individuals in an organization and these needs consequently, may tend to influence and stir up or stimulate a high level of staff performance.

This study is concerned with finding out the influence of motivation on teachers performance in secondary schools in Emohua Local Government Area of Rivers State. The specific questions which this study seek to answers include what are the major factors that motivated teachers? Does age have influence on the motivation of teachers educational qualification Educational six age experience and the like influence teachers performance. Study was to ascertain whether motivation has any influence on teachers performance. If this proves true it will ensure job satisfaction which will lead to higher productivity and achievement of educational objective.

\section{MATERIALS AND METHODS}

\section{Administration of Research Instrument Sample Selection}

The population studied comprises of secondary school teachers in Emohua Local Government Area of Rivers State. This local government area has 30 secondary schools. The stratified random sampling method was used to select 10 (ten) of the secondary schools. This is basically a rural local government and all the schools used were mixed. Three of the schools had boarding facilities. The selection spread round the whole local government area. The sample selected for the study comprised of one hundred (100) teachers, randomly selected from the total of 360 teachers employed in the selected secondary school. The simple random sampling method was used to select 10 teachers in each of the 10 schools selected for the study. The total number of subjects used for the study was 100 . 


\begin{tabular}{|c|c|c|c|c|}
\multicolumn{5}{|c|}{$\begin{array}{c}\text { Study Population } \\
\text { Table 1: }\end{array}$} \\
\hline S/No. & Schools & $\begin{array}{c}\text { Total No. of } \\
\text { Teachers }\end{array}$ & $\begin{array}{c}\text { Sample } \\
\text { Number }\end{array}$ & $\begin{array}{c}\text { Percentages of } \\
\text { Samples }\end{array}$ \\
\hline 1 & A & 30 & 10 & 33.3 \\
2 & B & 25 & 10 & 40 \\
3 & C & 30 & 10 & 33.3 \\
4 & D & 25 & 10 & 40 \\
5 & E & 36 & 10 & 27.8 \\
6 & F & 50 & 10 & 20 \\
7 & G & 45 & 10 & 22.2 \\
8 & H & 45 & 10 & 22.2 \\
9 & I & 26 & 10 & 38.5 \\
10 & J & 48 & 10 & 20.8 \\
\hline TOTAL & $\mathbf{1 0}$ & $\mathbf{3 6 0}$ & $\mathbf{1 0 0}$ & $\mathbf{2 7 . 8}$ \\
\hline
\end{tabular}

The simple random sampling method was used to select 10 teachers in each of the 10 schools selected for the study. The total number of subjects used for the study was 100 out of the total 360 teachers in the 10 schools selected for the sample which represents $27.8 \%$. The study sample for the teachers was 100 out of 1,000 teachers employed in Emohua Local Government Area. This represents 10\%.

\section{RESEARCH INSTRUMENT}

The study made use of a questionnaire tagged (I.M.S.S.T.P.Q.) meaning "Influence of Motivation on Secondary School Teachers' Performance Questionnaire" to collect data for the work. In some cases personal discussions and oral interviews were conducted to elicit information such as how many teachers the school had. How often teachers got promotions among other things. The instrument contained 35 items aimed at measuring the influence motivation has on teachers' performance in secondary schools. The Likert type scale was adopted but each item had a four-point scale weighted as follows: 4 - Strongly Agree, 3 - Agree, 2 - Disagree, 1

- Strongly Disagree. The questionnaire was in two parts. Part I consist of the respondents personal information such as the name of the school he or she teachers, his working experience, his age range, his/her subject area of specialization among other things. Part II on the other hand consisted of items on teachers' motivation and performance; hence it is subdivided into two sections. Section A consisted of 21 items which were meant to test teachers' motivation, while section 8 consisted of 14 items which were also meant to test the performance of teachers.

Table 2: Analysis (I.M.S.St.P.Q.) Respondents According To Age, Sex, And Qualification

\begin{tabular}{|c|c|c|c|c|}
\hline \multirow{2}{*}{ Sex } & \multicolumn{2}{|c|}{ Age } & \multicolumn{2}{c|}{ Qualification } \\
\cline { 2 - 5 } & $\begin{array}{c}\text { 30 Years and } \\
\text { Below }\end{array}$ & $\begin{array}{c}\text { 31 years and } \\
\text { Above }\end{array}$ & Degree holders & $\begin{array}{c}\text { N.C.E. and } \\
\text { Below }\end{array}$ \\
\hline Males & 25 & 20 & 30 & 15 \\
Females & 35 & 20 & 25 & 30 \\
\hline $\begin{array}{c}\text { Total No. of teachers } \\
\text { for each group }\end{array}$ & 60 & 40 & 55 & 45 \\
\hline
\end{tabular}

The above table shows an analysis of respondents by sex, Age and qualification. There were 25 male teachers that were below 30 years of age and the females under this group were 35, making a total of 60 male and female teachers who are 30 years and below. There were 20 male teachers who were 31 years old and above, while there were also 20 female teachers in the same age group. This brings the total to 40 teachers under this category. 
Concerning qualification, there were 30 males who were degree holders and 25 females who were also degree holders bringing the total number of degree holders to 55 Under N.C.E. and below we had 15 males and 30 females, making a total of 45 teachers under this category.

\section{METHOD OF DATA ANALYSIS}

The method of analysis used was cross-tabulation. the data collection was coded and tabulated by computing the frequencies and percentages of the various responses provided by the teachers.

Percentages were calculated on the basis of the following formula:

Percentage $=\underline{\mathrm{NR}} \times \underline{100}$

$$
\mathrm{n} 1
$$

Where NR $=$ The number of respondents belonging to a group.

$\mathrm{N}=$ Total number of respondents.

The percentages of respondents who agree or disagree is calculated by dividing the total number of respondents belonging to a group (for example male/female) by the total; number of respondents used for the study and you finally multiply that by 100 to get the percentage.

\section{RESULTS AND DISCUSSION}

The study was conducted to examine the influence of motivation on teachers' performance. The results are presented as: Cross tabulation of allowance and promotion factors, age, of allowance and promotion, qualification sex. Teachers' perception of other motivation factors. Perception of teachers' performance about their duties. trained and untrained teachers etc.

TABLE 3: Cross tabulation Of Allowances And Promotion Factors By Age

\begin{tabular}{|c|c|c|c|c|c|c|c|c|c|c|c|c|c|}
\hline $\begin{array}{l}\text { Variabl } \\
\text { e }\end{array}$ & \multirow{3}{*}{$\begin{array}{l}\text { Total } \\
\text { No of } \\
\text { teacher }\end{array}$} & \multicolumn{4}{|c|}{ Allowance } & \multicolumn{4}{|c|}{$\begin{array}{l}\text { Promotion according } \\
\text { to efficiency }\end{array}$} & \multicolumn{4}{|c|}{$\begin{array}{l}\text { Promotion according to } \\
\text { experience }\end{array}$} \\
\hline \multirow[t]{2}{*}{$\begin{array}{l}\text { Age } \\
\text { group }\end{array}$} & & \multicolumn{2}{|c|}{ agreed } & \multicolumn{2}{|c|}{$\begin{array}{c}\text { Disagree } \\
\mathrm{d}\end{array}$} & \multicolumn{2}{|c|}{ agreed } & \multicolumn{2}{|c|}{ disagreed } & \multicolumn{4}{|c|}{ Agreed disagreed } \\
\hline & & $\begin{array}{c}\mathrm{N} \\
\mathrm{O}\end{array}$ & $\%$ & No & $\%$ & No & $\%$ & No & $\%$ & No & $\%$ & No & $\%$ \\
\hline $\begin{array}{l}30 \text { yrs. } \\
\text { And } \\
\text { Below }\end{array}$ & 60 & $\begin{array}{l}1 \\
2\end{array}$ & 20 & 48 & 80 & 5 & 8 & 55 & 92 & 6 & 10 & 54 & 90 \\
\hline $\begin{array}{l}31 \text { yrs. } \\
\text { And } \\
\text { Above }\end{array}$ & 40 & 4 & 10 & 36 & 90 & 3 & 8 & 37 & 93 & 8 & 20 & 32 & 80 \\
\hline
\end{tabular}

Table 3 shows that among 60 teachers who are 30 years and below, 12 teachers $(20 \%$ agreed that car loans, car basic allowance, housing and transport allowances and leave bonuses are given to teachers. On the other hand, 48 teachers $(70 \%)$ disagreed that they are being given the above benefits. other factor considered include acceptance of responsibility, preparation of teaching aids etc.

\section{Acceptance of Responsibilities}

Here the result shows that 40 of the younger teachers agreed that teachers accept responsibilities.willingly this number represents (67\%) while 20 of the teachers disagreed with the statement (33\%).Among the older teachers 34 out of the 40 teachers (85\%) agreed, while 6 representing (15\%)disagreed.This also means that the two group take their work very seriously and accept responsibilities willingly even though the older group scored higher percentage.

\section{Teaching Aids Preparation}

For teaching Aids preparation 40 out of the 60 teachers (67\%) agreed that they prepared aids for their lessons while 20 of them (33\%) disagreed with the statement. Among the teachers who are 31 years and above 34 out of the 40 teachers $(85 \%)$ agreed with the statement while 6 of them disagreed (15\%). The result shows that the older teachers take the preparation of teachers aids more seriously than the younger ones though the younger teachers too are trying. 
Table 4: Teachers Perception of Other Motivating Factors

\begin{tabular}{|l|l|l|l|l|}
\hline MOTIVATING & $\begin{array}{l}\text { No.of } \\
\text { Teachers } \\
\text { Agreed }\end{array}$ & $\begin{array}{l}\text { \% } \\
\text { Agreed }\end{array}$ & $\begin{array}{l}\text { No. of } \\
\text { Teachers } \\
\text { Disagreed }\end{array}$ & $\begin{array}{l}\% \\
\text { Disagreed }\end{array}$ \\
\hline Attitude to work & 100 & 180 & - & - \\
Annual leave & 15 & 15 & 85 & 85 \\
Prompt payment of salaries & 13 & 13 & 87 & 87 \\
Choice of lecture periods & - & - & 100 & 100 \\
Teachers involvement in decision making & & & & \\
Annual get -together parties & 20 & 20 & 80 & 80 \\
Send-off parties & 50 & 50 & 50 & 50 \\
Memorable presents & 56 & 56 & 44 & 44 \\
Principals personal help & 40 & 40 & 60 & 60 \\
Constants supervision of work & 30 & 30 & 70 & 70 \\
Professional help & 50 & 50 & 50 & 50 \\
Reading lesion note by principal & 15 & 15 & 85 & 85 \\
Attendance register & 5 & 5 & 95 & 95 \\
Movement book & 75 & 75 & 26 & 26 \\
Facilities & 70 & 70 & 30 & 30 \\
Response to teacher's demand & 15 & 15 & 85 & 85 \\
Adequate staff development & 10 & 10 & 90 & 90 \\
Accommodation & 20 & 20 & 80 & 80 \\
& 13 & 13 & 87 & 87 \\
& & & \\
\hline
\end{tabular}

On the issues of whether motivation improves teachers attitude to work, all the 100 teachers used for study agreed with the statement. This means that if teachers are properly motivated their productivity in the school system will be increased. Concerning the statement on whether teachers are giving annual leave at their own discretion, 15 teachers out of 100 teachers used for the study (15\%)agreed while (85\%) disagreed. This means that choice of annual leave is not used as a motivating factors in our schools. On whether teachers are paid regularly, 13 out of the 100 teachers (13\%) agreed with this while 85 teachers (87\%) disagreed.This resultshows that teachersare not paid promptly and regularly hence teachers are not motivated through prompt payment.With regard to the choice of lecture periods, none of the teacher agreed that they have a choice as to the choosing of the periods they used in teaching. This is also means that choice of lecture period is not used as a motivating factor.Concerning the statement on whether teachers are involved in decision making, only 20 teachers out of the 100 teachers used for the research agreed (20\%) while the 80 teachers disagreed representing (80\%). This also means that teachers are not involved in the decision making process of their schools hence it is not used as a motivating factor to teachers. Regarding the aspect annual get-together parties, 50 out of 100 teachers $(50 \%)$ agreed while 50 representing (50\%) again disagreed that annual get-together parties are organized. This means that annual get-together isused in motivating teachers slightly and not much since half of the teachers disagreed.On the issues of whether send-off parties are organized by the school for out-going teachers, 56 out of the 100 used for the study (56\%) agreed, while 44 teachers (44\%) disagreed. This means that send-off parties is used as motivating factors for teachers.Presentation of memorable presents is another factor that can be used to motivate teachers, but it is not being used properly since only 40 out the 100 teachers $(40 \%)$ agreed to the statement while 60 of them $(60 \%)$ disagreed. With regard to principal's personal help. 30 out of the 100 teachers agreed $(30 \%)$ while 70 out of the 100 teachers $(70 \%)$ disagreed. This means that this is not used as a motivating factor in the schools. On the aspect of supervision, 50 out of 100 teachers agreed (50\%) that there is constant supervision of teacher's work. $50 \%$ of the teachers also disagreed that there is supervision.Concerning the statement on whether principals render professional help to teachers, 15 out of 100 teachers used for the study agreed representing (15\%), while 85 teachers $(85 \%)$ disagreed. This means that the principals are not helping the teachers professionally, and this also does not motivate the teachers. As for lesion notes, 5 teachers out of 100 teachers used (5\%) alone agreed that principals have time to read teachers lesions notes. On the aspect of attendance register, 74 teachers agreed (74\%) while 26 of the teachers also disagreed (26\%). This shows that keeping of attendance register in schools can be used as a motivating factor.

\section{CONCLUSION AND RECOMMENDATIONS}

This study was conducted in order to find the influence motivation has on the performance of teachers in secondary schools in Emohua Local government area of Rivers State. The sample consisted of secondary school teachers in the above local government area. 100 questionnaires were administered and all the 100 were 
returned. This represents 100 percent response or return rate.The study sought to answer questions: such asWhat are the major factors that motivates teachers?Does Age influence motivation of teachers:Does educational qualification have any influence on the motivation of teachersTo what extent does age influence the performance of teachers?Does sex have any influence on the performance of teachers?To what extent would years of teaching Experience influence teacher performance?To what extent does professional qualification of teachers affect their performance?

\section{CONCLUSIONS}

The following conclusions could be drawn on the basis of data collected and analyzed in this study. The factors that are currently being used to motivate teachers in the school's which are, annual get- together parties, organizing send-off parties for teachers on transfer, constant supervision of teachers' work, provision of attendance register and provision of movement books have little or no influence on the motivation of teachers That age has no influence on the motivation of teachers.Educational qualification too has no influence on the motivation of teachers. Younger teachers seem to perform their duties better than the older teachers. The male teachers were found to be more hardworking than the female teachers. The less experienced teachers than the more experienced teachers.Professional teachers seem to perform their duties better than the non- professional teachers.That motivation has positive influence on teachers' performance general.

\section{RECOMMENDATIONS}

As a result of the findings, the following recommendations are suggested:That the management of the state secondary schools in Rivers State should make use of correct motivational strategies such as attitudes motivation, incentives, and recognition.Since age since to influence performance the age group that is found to perform better should be employed for better results?There should be workshops which should guide the management on the right factors that motivate teachers for better performance and higher productivity.The government should always try as such as possible to pay teachers' salaries promptly and regularly, and also make efforts to pay attention to teachers, demands and complaints. The government or the management should provide accommodation for teachers on the school compound, but where there are none, enough allowances should be given to teachers to pay for their rents.Every teacher should be given the opportunity to develop him/herself through study- leave with pay.Finally, facilities should be provided for teachers in order to perform their duties more affectively.Also as the study covered only Emohua Local government area of Rivers State so I suggest that a similar study be carried out either in the same state but in different local government areas or in other states of the federation and beyond. The findings of this study can only be regarded as a beginning towards many more researches into motivation and the influence it has on performance. The study used the descriptive survey method so I suggest that further studies be carried out using other research methods, such as case study using different schools with specific conditions.It is further suggested that further research work should try and use different method of analysis apart from the cross tabulation and the simple percentages used for this work.

\section{REFERENCES}

[1] Adeniyi, M.F. (1991) Motivation as a correlate of job performance: A case study of Ogun State University Teaching Staff. Unpublished M.ED. Dissertation, University of Ibadan.

[2] Ajibade, A.O. (1984) "The relationship between Principals' Leadership styles and staff motivation". Unpublished Ph.D. Thesis, University of Ibadan.

[3] Ajayi, S.A. (1981) "Job Satisfaction and Commitment among Nigerian University Teachers". Unpolished Ph.D. Thesis, University of Ibadan.

[4] Ajayi, A.O. (1983) Basic Concepts in Economic, Planning and Administration of Education, Ibadan.

[5] Ajayi, S. G. (2009). Statistical method for practice and research: (2nded.)Delhi:SAGE

[6] Argyris, C. (1957) Personality and Organization: The Conflict between the system and the individual. New York: Herper and Brothers.

[7] Aregbesola, B.K. (1992) Influence of Motivation on Secondary School Teachers' productivity in Akure Local Government Area, Unpublished M.Ed., Dissertation, University of Ibadan.

[8] Atkinson, J.W. (1961) An Introduction to Motivation. New Jersey: Van NostrandRunhold.

[9] Awe, A.B. (1981) "School Climates and Teachers' Morale in Ibadan Municipal Secondary Schools". Unpublished M.Ed. Dissertation, , University of Ibadan.

[10] Beach, D.S. (1975) Managing People at work ( $2^{\text {nd }}$ Edition). New York: Macmillan.

[11] Darwin, C. (1936) Origin of Species. New York: Modern Library.

[12] Drucker, P.F. (1978) People and Performance. The best of Peter Drucker on Management, London: Heineman, W. Ltd., 1979, p. 172.

e-ISSN: 2320-7388,P-ISSN: 2320-737X Volume 7, Issue 1 Ver. II (Jan. - Feb. 2017) pp 00-00 
[13] Duncan, W. J. ( 1978) Essentiable of Management. IIIInus. The Drydein press, U. S . A.,

[14] Fayol, H. (1949) General and Industrial Management. Trans withStarrs, London: Sir Isaac Pictman and Sons,

[15] Freud, S. W. (1933) New Introductory Lecture on Psycho-analysis.New York: Norton,

[16] Goldman, E.(2000).The significance of leadership style. Educational, Leadership,55(7),20-22

[17] Hackman, M.Z.\& Johnson, C.E.(2009). Leadership: A communication perspective,(5 ${ }^{\text {th }}$ ed).Long Grove, IL:Waveland press.

[18] Herzberg, F. (1966) (1966) Work and Nature of Man. New York: World PublishingCo., A mentor book, New American Library,

[19] Hull, C. L. ( 1943) Principle of Behaviour. New York: AppletonCentury, Crofts, Inc.,

[20] James, W. (1980 ) Principle of Psychology. New York: Holt,

[21] James W. (1911.) Human Behaviour in Organisation. New York: Holt,

[22] Inbar, D.(2009). Educational leadership in an era of contradictions,Educational Echo, 83 (4): 52 54.(Hebrew)

[23] Kootnz, H. O. et. Al. ( 1980) ( 1954.) Management. New York: Mc Graw HillInternational Inc., Katz, R. L. et al. Human Organisational and Worker Motivation.In L. Reed, Tripp (ed.) International Conflict. New YorkMc Graw Hill,

[24] Likert, R. ( 1952) Motivational Dimensions of Administration in American'sManagement Crisis.Chicago: Public AdministrationService,

[25] Lofgwish, R. et al. ( 1981 ) "Comprehensive Study of the Motivation For Occupational Preference among Staff and StudentNurses in Ibadan",.

[26] Luthans, F. ( 1979) OrganisationalBehaviour. Kogajusha, McGraw Hill,

[27] Mayo, E. ( 1933) the Human Problem of an Industrial Civilization.Boston: Harward Graduate School of Business Amin.,

[28] Maslow, A. ( 1943) The Theory of Human Motivation, PsychologicalReview,

[29] McCielland, D. C. et al. ( 1960) The Achievement Motive: AppletonCentury, New York,

[30] McGregor, ( 1960) he Human Side of Enterprise. New York:Mc Graw Hill,

[31] Meindinyo, R.O.K, Ibara, E.C. Tuatongha C. (2017). Leadership styles and teachers job satisfaction. OSR Journal of Research and Education (IOSR-JRME)

[32] Nwankwo, J. I. ( 1982) Educational Administration: Theory andPractice. New Delhi: Vikas Publishing House, PVT

[33] Nwagu, N.A. ( 1976) Universal Primary Education in Nigeria, IssuesProspects and Problems. Benin City: Ethiope PublishingCorporation,Nigerian Observer of May 30, 1983.

[34] Obilade, S. O “ ( 1986) The peter Principles and AdministrativeEffectiveness in the Nigerian Educational System” African Journal of Educational Management, Vol. , No. 1, P.3

[35] Ogunsanya,. (1981 ) "Relationship between' job satisfaction,Teachers productivity and school academic goals".,

[36] Unpublished Ph. D. Thesis, University of Ibadan,

[37] Ogunsanye, M. “ ( 1986) Personnel Motivation and Performance” .Seminar paper presented in the Department of EducationalManagement, University of Ibadan, Unpublished,

[38] Onyejiaku, F. E. ( 1977) Need Satisfaction and Job performance amongNigerian Teachers. Ibadan, Unpublished M. Phil,Dissertation,

[39] Porter, L. W. “ ( 1962) Job Attitudes in Management, Perceived Deficiencies in Need Fulfilment as a Function of JobLevel”. Journal of Applied Psychology, December,PP. 375-384 